\title{
Article
}

\section{The spectacle of science aloft}

\section{Cristina Olivotto}

Since the first pioneering balloon flight undertaken in France in 1783, aerial ascents became an ordinary show for the citizens of the great European cities until the end of the XIX century. Scientists welcomed balloons as an extraordinary device to explore the aerial ocean and find answers to their questions. At the same time, due to the theatricality of ballooning, sky became a unique stage where science could make an exhibition of itself. Namely, ballooning was not only a scientific device, but a way to communicate science as well. Starting from studies concerning the public facet of aerial ascents and from the reports of the aeronauts themselves, this essay explores the importance of balloon flights in growing the public sphere of science. Also, the reasons that led scientists to exploit "the show of science aloft" (earning funds, public support, dissemination of scientific culture...) will be presented and discussed.

\section{Introduction}

After the first aerial ascent in 1783, several scientists believed that ballooning could become an irreplaceable device to explore the upper atmosphere: the whole XIX century "gave birth to countless endeavours to render the balloon as navigable in air as the ship at sea". ${ }^{1}$ From an analysis of the aerial ascents undertaken for scientific purposes and the characters of the scientists who organized and performed them - no more than 10 aeronauts from the beginning of the century to 1875 - an important feature emerges: ballooning - due to its proper nature - became a powerful tool in attiring a general public toward science, more effectively than scientific papers and oral lectures.

This essay focuses on the public facet of the scientific experiments performed on balloons in a period from the end of XVIII century to the end of the XIX century - during which ballooning was trying to propose itself as a reliable scientific tool; it points out how the public image of ballooning could influence the decision to support the scientific exploration of the atmosphere by balloons and how "balloonmania" was exploited by scientists in order to turn it towards their objectives (the case of James Glaisher is highly representative).

Starting from the analysis offered by the historians Mi Gyung Kim, Jennifer Tucker and Michael Connaughton, who focused their interests on the public facet of aerial ascents in different contexts (from a social point of view; in Great Britain; in the United States respectively), the aim of this paper is to discuss the importance of the "show of science aloft" in the acceptance of balloons as a scientific tool. That is, to stress the scientific fallout of ballooning popular enthusiasm, besides its social and political value.

Scientists exploited the public sphere of ascents for different reasons: to earn funds, find public support, shape (or not) a public image of science, establish collaborations, interest the public in science, glorify the power. Moreover, the ambiguous nature of the balloon ascents - a scientific enterprise or a vulgar show - determined the different attitude of scientific institutions towards it.

At the same time, papers and books reported the accounts of the voyages because of their appeal, thus communicating to a wide public some of the hot topics of the forefront science. Thanks to balloons, science became fashionable: "Balloon broadened the audience for science beyond anybody's imagination". 2

The account hereafter offered is based on historical published essays and papers, and on the original scientific reports published from the aeronauts themselves, which nowadays are very rare and precious documents. Some of the most famous tales and novels written by Edgar Allan Poe and Jules Verne have been also taken account to discuss the great popularity of topics related to ballooning among general readers. 


\section{Scientific ballooning during the XIX century}

Scientific discoveries in general even those from which men expect the most advantage, like those of the compass and the steam-engine, were greeted at first with contempt, or at the best with indifference. Political events, and the fortunes of armies monopolised almost entirely the attention of the people. But to this rule there are two exceptions: the discoveries of America and of aerostatics, the advents of Columbus and of Montgolfier. ${ }^{3}$

At the end of the XVIII century, meteorologists regularly used barometers, hygrometers and thermometers to measure atmospheric variables, but notwithstanding their accuracy, these measurements were obviously limited since they were performed on the ground and could not explore the dependence of the variables from height. Some scientists, like Horace Benedicte de Saussure, Alexander von Humboldt and Jean-Andrè De Luc climbed high mountains to perform high-altitude experiments but the results were not enough reliable due to the extreme conditions of the observations. ${ }^{4}$

Therefore, the spectacular enterprises of the first aeronauts (Pilatre de Rozier, Jacques Charles, Pierre Blanchard...) excited great interest among men of science. The scientists, physicists and chemists first, welcomed balloons as an extraordinary device to explore the aerial ocean and to find answers for unsolved puzzles. Fifty years later the first ascent, in 1841, in Paris and in London societies for the knowledge of atmospheric physics, which used balloons for their researches, were born. ${ }^{5}$

The earliest flights can be seen somehow as the first scientific ones because no one knew their possible effects, but we can consider the first flight with a scientific purpose the one of John Jeffries, an American physician, and Pierre Blanchard in 1784. After this flight, many other ones followed in France, Russia, England, Italy and Germany during the XIX century, providing fairly good results, for meteorology purposes above all. France and England became, though different in attitude and purposes, the two countries which most supported the scientific exploration of the air and conceived the best research programmes concerning the flights.

From a wider point of view, the exploration of the aerial oceans and the researches concerning the atmosphere, the geo-magnetic field, tides, winds and weather were strongly developed from the XVIII century onward, according to a renewed interest towards unknown lands: it was time for a global knowledge of the terrestrial phenomena and scientific ballooning became part of this wide research programme of exploration. Among the studies, which could be performed at high altitude, the meteorology, namely the measurements of temperature, pressure, humidity, dew point, was - quite obviously - the first aim of the scientists-aeronauts. Moreover, physicists could perform optics experiments, study the electricity of the air, the sound propagation and the characteristics of the terrestrial magnetic field. The astronomers could observe the sky from a favourite point of view and physicians study the response of human and animal body to the extreme conditions of pressure and temperature. Last but not least, the chemists could measure the ratio of the component of the atmosphere at different height; ${ }^{6}$ the first aerial ascents greatly influenced the birth of modern chemistry. ${ }^{7}$

Among the most famous scientific flights, there are the ones of Joseph Louis Gay-Lussac and Jean Baptiste Biot (1804), Carlo Brioschi (1808, the first scientific flight performed in Italy), James Glaisher (1862-6), Camille Flammarion (1867-8), Thèodore Sivel and Joseph Croce-Spinelli (1875), whose death aloft set a mark-point in the history of scientific ballooning because it showed the importance of oxygen masks and the danger of high-altitude manned flights. After the tragedy (1875), ballooning changed its nature from an almost individual adventurous endeavour to a systematic and reliable device for investigating science.

The scientists - physicians (e.g. Jeffries), chemists (e.g. Barral), physicists (e.g. Biot) or astronomers (e.g. Flammarion) - used to organize the flights by themselves, from the planning to the performance of the experiments and the analysis of the collected data. Two or at most three persons were carried on the balloon; they had to control the flight and to do the measurements as well. During the XIX century flights, a lot of experiments were issued on the balloon in order to do as many observations as possible. Even if the ascent had a specific aim (like the Gay-Lussac's one, focused on checking previous results on the terrestrial magnetic field), experiments ranging from the collection of air samples to the human physiology were performed: the aeronauts spent their time "running" from a measure to another, trying 
to catch the proper moment due to the balloon instability. The fewness of the flights caused this "promiscuity": the ascents were rare occasions, which scientists should spoil as much as they could.

The topics to be inquired got narrower through the years, when the scientists became aware that the electrical and magnetic measurements required a more sophisticated approach than the available one. The contribute of the several ascents organized for a scientific purpose - also those part of a well organized research programme - to the advancement of scientific knowledge was not comparable with the effort spent by the scientists in organizing the ascents. The reason of this partial failure was mainly to be attributed to the extreme conditions in which the aeronauts performed their measurements and to the inadequacy of the used instruments. It is today known that even the most prominent aeronauts like Glaisher, did not use proper instruments for their observations at high altitudes. ${ }^{8}$

Among all the fields of research, the meteorological ones were the most important, especially since the end of XIX century; on the contrary the measurements concerning electricity and magnetic field were almost not reliable at all. Nevertheless, the technical progresses obtained during XIX century provided important results during the following century, not only in meteorology but also in physics - due mostly to the improvement of sounding balloons. In this framework, the value of ballooning as a tool for popularize science becomes even greater.

\section{Different images, different attitudes}

In England, the ballooning age started in the second half of the XIX century, when, after the first ascents performed by charlatans, the scientific elites became convinced of ballooning utility. Vincenzo Lunardi, secretary of the Neapolitan ambassador in London, organized the first manned flight in Great Britain in 1784, and set the tone for the following flights: the aeronauts were adventurers seeking for fame and fortune. ${ }^{9}$ The aim of the flights was the public entertainment and scientific purposes were left out until the second half of the XIX century, except for the flight of Jeffries, who, however, was an American physicist fling with a French aeronaut. For British scientists, ballooning was no more than an ambiguous entertainment for the masses, negatively associated with French attitude towards fancy and fashionable phenomena. ${ }^{10}$ Both the Royal Society and the American Philosophical Society (APS) (inspired from the Royal Society ${ }^{11}$ ) were extremely careful with ballooning. ${ }^{12}$ In a letter to Benjamin Franklin, Joseph Banks wrote: "an inclination in the more respectable part of the Royal Society to guard against 'Balloomania'... and not to patronize Balloons... till some experiments likely to prove beneficial either to Society or Science is proposed to be annexed to them". ${ }^{13}$ Banks, one of the most influent people of the scientific British community, was able to force his opinion on balloons.

Though the communication of science was strongly auspicated by British scientists, ballooning (and balloonmania) was a too much controversial phenomenon to be accepted and promoted. The line between spectacle and science was often difficult to draw and the effect of popularize science by ballooning could be even a drawback. ${ }^{14}$

In America, the young scientific community was concerned with the construction of a professional and useful image of science, just the opposite of a speculative or spectacular science. Ballooning did not fit with this project and thus, in spite of its futuristic possibilities, was not supported. As a consequence, the APS and the Royal Society ${ }^{15}$ decided not to embrace a scientific and technological endeavour so popular and controversial. In this perspective, we can also understand why Pierre Blanchard, even though he was the first to fly in America, was not admitted as a member of the American Philosophical Society. ${ }^{16}$

On an opposite attitude, there was the British Association. Founded in 1831, it had two main goals, as stated in the opening remarks: to bring together different disciplines and to heighten public awareness of science. ${ }^{17}$ Ballooning could achieve both these aims and, as a consequence, in 1859 the Association organized the most important series of scientific balloon ascents in Great Britain undertaken by James Glaisher. The flights eventually changed the British opinion towards scientific ballooning and inspired the enterprises of the French aeronauts ${ }^{18}$ at the end of the century, even though they add spectacularity to the British pragmatic approach. ${ }^{19}$

At the beginning of the XIX century, in France, as Franklin wrote to Banks, the scientific community was less conservative than the English one and "not so much afraid of been laughed at" if aeronautics would revealed a big mistake" ${ }^{20}$ French scientists and cultural elites had a patriotic interest to introduce a general audience to science. Ballooning was considered to be an important tool to promote science and, 
as a consequence, the government that supported it. ${ }^{21}$ Sky became a theatre where the king's glory could be displayed and ballooning became more powerful than papers or speeches to shape a popular opinion on science. The main scientific institutions, as the French Academy, spent time and money to support and develop ballooning, as suggested by influential scientists, like Pierre Simon Laplace.

\section{"Balloonmania"}

Hitherto aerial voyages have been undertaken merely for the gratification of the public. ${ }^{22}$

About 250,000 spectators were present at the first manned ascents in Great Britain performed by Vincenzo Lunardi and Jean-Pierre Blanchard. ${ }^{23}$ More than a half of citizens of Paris (about 400,000 people) assisted to the first aerial events: a mixed crowd, made up of the king and his court, scientists and men of letters, poors and illiterates: a democratic crowd, in one word; ${ }^{24}$ ballooning was attractive for all, passing over social divisions ${ }^{25}$ because it could satisfy the expectations of a broad audience. It was a breakthrough that witnessed the advancement of knowledge, the progress of human talent and could impress because of its novelty, a thing never seen before but always dreamed: be able to flight.

There was nor party or celebration without a balloon ascent, in London or Paris. The shows were more and more spectacular (parachutes, night flights, with animals or fireworks) to enjoy a sensation-loving public $^{26}$ to the point that, due to the enormous increase of the number of balloons ascents, in 1784 the police in Paris forbade to make ascensions without permission, according it just to scientists. ${ }^{27}$

The newspapers regularly reported the flights and contributed to the spread of the so-called "Balloonmania": there were even hats, skirts and theatrical representations inspired by balloons. ${ }^{28}$ People were strongly interested in aeronautics and could become quite outrageous if a balloon-show failed: ${ }^{29}$ balloon ascents were an emotional show and the public was involved with the enterprise and feared for their heroes, the aeronauts.

A significant episode concerns Etienne Montgolfier who, in October 1783, was preparing a flight and one of the organizers was frequently asked to secure a place for the show. The requests became so continual that he wrote on the "The Journal of Paris" that the experiment would be interesting just for scientists and not for generic public; nonetheless many spectators attended to the launch! $!^{30}$

The literature of the period confirms the popularity of aerial ascents, and fantasy tales based on travels in the skies were written by famous authors and read by enthusiastic readers.

The two most famous examples showing the fashionable appeal of ballooning during the XIX century, were the books and novels written by Jules Verne in France and Edgar Allan Poe in America; their stories also show the deep scientific culture of their authors concerning balloons.

In 1863 "Five weeks in balloon" was published: it was presented by Jules Verne as a real diary of a scientific voyage of exploration. Verne invented a new kind of balloons able to permit the team, led by a scientist, to explore the unknown lands of Africa. Verne himself admitted that when he started to write this romance, he did not believe in the practical use of balloons. Nonetheless, he knew perfectly the state of the art of aerostation, and from this background he could describe fantasy balloons, which seemed real. He was a usual reader of "La Nature" - an important journal of scientific divulgation - whose main contributors, Gaston Tissandier and Camille Flammarion, were both aeronauts and communicators. ${ }^{31}$ Moreover, he sought out and interviewed many notable scientists and balloonists. ${ }^{32}$ Verne wrote about balloons in many of his romances, like "Around the world in 80 days", "The mysterious island", "Voyage in a balloon". In 1873 the French writer made his first and unique balloon ascent, while he was starting to write "The mysterious island". At the end of the voyage he stated "it's a sort of dream, but always too short!".

Verne had read Edgar Allan Poe's novels, translated in French in 1856 by Charles Baudelaire, "The balloon hoax" and "The unparalleled adventure of one Hans Pfaall" both about ballooning. In the first of these weird stories, "The ballon hoax", an English team decides to flight over the Channel but gets lost over the ocean. The story was presented as a real news published on "The New York Sun" in 1844 and pays great attention to technical details, suggesting Poe's great knowledge of aerostation, just like Verne. Writing the tale, he was probably inspired by the flight of the great balloon called Nassau and by Charles Green's (one of the most famous English aeronaut of the time) subsequent transatlantic project. ${ }^{33}$ 
During the pioneering age of ballooning, "the ballooning craze [...] [made] the impossible and seemingly inexplicable appear reasonable and commonplace, 34 and that was probably one of the reasons of success of this kind of realistic novels.

\section{Communicate science with balloons}

It [the balloon] has gratified the desire natural to us all to view the earth in a new aspect, and to sustain ourselves in an element hitherto the exclusive domain of birds and insects. We have been enabled to ascend among the phenomena of the heavens, and to exchange conjecture for instrumental facts, recorded at elevations exceeding the highest mountains of the Earth. ${ }^{35}$

At the end of the XVIII century, ballooning represented a quite innovative way to communicate not only enthusiasm or political ideas, ${ }^{36}$ but science as well. A show could reach more people than a scientific report and in some way it gave the opportunity to an illiterate and plebeian public to enter in contact with science. Without the aid of printed papers and journals, personal contacts, membership in academies, people could however be up-to-date with some of the scientific issues of the moment. Moreover, newspapers regularly reported the accounts of the ascents and often the aeronauts themselves wrote memories and reports. The account of Montgolfier brothers' flight, for example, was reported in the physics section of the very diffused "Journal de Paris".

An interesting account of a flight is the one provided by Benjamin Franklin, who was ambassador in Paris when Jacques Charles made his aerial experiment together with Robert, the constructor of the machine. He wrote to Joseph Banks (president of the Royal Society) that "never before was a philosophical experiment so magnificently attended" and referred to Charles both as a "professor of experimental philosophy, and a zealous promoter of that science". 37 In the words of Louis-Sebastien Mercier "It was a moment which can never be repeated, the most astounding achievement the science of physics has yet given to the world". 38

Due to the public facet of the scientific flights, in the second half of the XIX century, James Glaisher was finally able to shape a new image of ballooning in Great Britain, not considered as an exploration and innovation tool, but as the symbol of excited and illiterate crowds since the first ascents. ${ }^{39} \mathrm{He}$ aimed at showing everybody the scientific value of ballooning and in doing so he pursued a large communication programme. ${ }^{40}$ As the historian Jennifer Tucker stated: "Glaisher transported science into the air, but in so doing he had to strike an elusive balance between science and show".

Balloon ascents and lectures for generic audiences were the means through which he explained how balloons could be useful tools for science. Glaisher tried to disrupt the public image of aeronauts as adventurers and was very concerned "to make the balloon a philosophical instrument, instead of an object of exhibition, or a vehicle for carrying into the higher regions of the air excursionists desirous of excitement, mere seekers after adventure". ${ }^{42}$ Hence, he proposed himself as a hero of discovery, fully devoted to a kind of science characterized from accurate measurements and well-organized experiments. Henry Coxwell - the aeronaut who used to fly with Glaisher - shared his aim and helped Glaisher to set a difference between scientific and popular flights; ${ }^{43}$ he wrote to Glaisher that "the British Associations ascents should be kept distinct from those merely undertaken for popularity or adventure, indeed some difficulty presents itself in combining them". The reason of this warning comes from the great appealing of public flights organized by Glaisher. In 1863 one the ascents excited more interest than any other event connected with the annual meeting of the British Association. ${ }^{44}$ A crowd of about 3,000 people listened to his report and watched at the flight. During balloon ascents - as the case of James Glaisher very well bears - science, adventure and spectatorship could finally met.

That is also the reason why some of the scientists-aeronauts thought that scientific popularization was such an important topic that they dedicated to it effectively: James Glaisher, Camille Flammarion, Jacques Charles and Gaston Tissandier were popularizers of aerial enterprise. They wrote about ballooning on popular journals and even wrote books; Tissandier was also the editor of "La Nature", the most famous French journal about popular science.

Besides the promotional purposes, other prominent aeronauts, Glaisher first, had practical reasons to popularize their ascents in newspapers. For his meteorological measurements he needed many observers in the country and the day before each ascent invited his public from the pages of "The Daily Telegraph" 
to take observations on temperature and contribute to his research. Another example comes from Jacques Charles' flights, which were sponsored by public subscriptions; hence he was forced to invite to his flights as many people as possible, but trying to select the wealthiest participants: indeed, the kind of public who attended the flight eventually determined its success!

\section{Conclusions}

Since the end of the XVIII century, the interest of the general public towards science grew more and more, and people became aware of the importance of science for the advancement of knowledge and of its utility. There was a growing participation in activities like lectures, public demonstrations and the reading of periodicals: as a consequence, science was supported also by the public opinion and the public sphere became an important feature of the XIX century science. ${ }^{45}$

The ballooning age began in this fruitful context and its innate theatricality influenced the willingness to become a device to explore nature. Many people, composed both by the mass and cultural elites, attended the ascents and shared the passion for ballooning. Newspapers published many reports of the ascents; writers wrote stories about balloons: the "balloonmania" was spreading.

The decision to support and sponsor research programmes about balloon flights strictly depended to the impact of ballooning on the national opinion-makers. In French sky became a stage where King's power could be celebrated through balloons; on the contrary in the United States and in Great Britain ballooning was not sponsored at all, until its image dramatically changed in the second half of the century, mainly due to the engagement of James Glaisher.

Beside the institutional arguments, the power of balloons in communicating science was exploited by many scientists; the reasons which led them to actively communicate their experiments (though a constant attention paid from the public to aeronauts could be annoying) were different and, curiously, not so distant from the nowadays arguments concerning the importance of science communication. The quest for sponsors (Jacques Charles), the support of public opinion in order to obtain an institutional support (James Glaisher), the establishment of collaborations (James Glaisher), the genuine interest to popularize science as a cultural mission (Camille Flammarion, Gaston Tissandier) are the main reasons of actively popularizing science ballooning, starting from its spectacularity.

Hence, scientific ballooning during the XIX century represent an interesting case study of the importance of science communication in modern age and show how the public sphere of science - in this case, scientific experiments aloft - play a fundamental role in the understanding of the processes which lead to the success of a research programme. Moreover, especially for public oriented science, like ballooning, the relationship among the public, the scientists and the supporters is so strict that scientists themselves often base their success - emotional and economical - on their ability in gaining popular support.

\section{Notes and references}

${ }^{1}$ G. Sarton, Book Review, the history of aeronautics in Great Britain, ISIS 7 (3) (1925) 521.

${ }^{2}$ M.G. Kim, Public science: hydrogen balloons and Lavoisier's decomposition of water, Annals of Science, 63 (2006) 291.

3 Dominique Francois Jean Arago in: Marion, Fulgence (1870). Wonderful balloon ascents; or, the conquest of the skies. A history of balloons and balloon voyages, London (1870).

${ }^{4}$ Scientists-aeronauts like Gaston Tissandier and James Glaisher pointed out the better reliability of measurements made on balloons: see for example: J. Glaisher, C. Flammarion, W. De Fonvielle, G. Tissandier, Voyages aèriens, Paris, Hachette (1869), pp. 5-11.

5 M. Majrani, Aerostati: veloci come il vento, leggeri più dell'aria, Cinisello Balsamo: Silvana (1999) p. 72.

6 "The aeronaut, the meteorologist, the astronomer [...] is in the most invidiable situation for the study of atmosphere". In: C. Flammarion, L'atmosphere. Meteorologie populaire, Paris (1887) p. 142.

7 See for example: A. Scott, Il pallone aerostatico e la nascita della chimica moderna, Le Scienze 82 (1984) 84; P. Austerfield, From hot air to hydrogen: filling and flying the early gas balloons, Endeavour 14 (1990) 194.

8 L. Rolt, The aeronauts. A history of ballooning , 1783-1903, London, Longmans (1966) p. 192.

${ }^{9}$ For an extensive account of the adventurous-side of the first aerial ascents, see: R. Gillespie, Ballooning in France and Britain, 1783-1786: aerostation and adventurism, ISIS 75 (1984) 248 
${ }^{10}$ P. Keen, The Balloonomania: science and spectacle in 1780s England, Eighteenth-Century Studies 39 (2006) 507.

${ }^{11}$ M. Connaughton, Ballomania. The American Philosophical society and Eighteenth century science, Journal of American Culture 7 (1984) 71

12 J. Tucker, Voyages of discovery on oceans of air, Osiris 11 (1996) 144.

${ }^{13}$ Connaughton (1984). Op. cit., p. 71.

${ }^{14}$ Keen (2006). Op. cit.,

${ }^{15}$ The only member of the Royal Society who gave attention to ballooning was Tiberio Cavallo, an experimenter who was engaged in popularizing science.

${ }^{16}$ Blanchard was thwarted in France too by the scientific elite that controlled ballooning. In: Connaughton (1984). Op. cit., p. 74.

${ }^{17}$ Tucker (1996). Op. cit., p. 149

${ }^{18}$ Scott (1984). Op. cit., p. 84

19 - (1869), Meteorologia aeronautica, Annuario Scientifico ed Industriale, p. 126

${ }^{20}$ Connaughton (1984). Op. cit. , p. 74.

${ }^{21}$ M. Gyung Kim, Balloon mania: news in the air, Endeavour 28 (2004) 149.

${ }^{22}$ Sacharof, An account of the aerial voyage undertaken at Petersburgh on the 30th of January 1804, Philosophical Magazine $\mathbf{8 3}$ (1805) 193.

${ }^{23}$ T. Crouch, The eagle aloft, Washington: Smithsonian Institution (1983), p. 78.

${ }^{24}$ Kim Gyung (2004). Op. cit., p. 149.

${ }^{25}$ G. Tissandier, Histoire des ballons et des àronautes cèlèbres, 1783-1800, Paris (1887), p. 79.

${ }^{26}$ Rolt (1966). Op. cit., p. 103. "Eventually, by the end of the XIX century the old professional showmen aeronauts were almost disappeared: balloon ascents with fireworks, acrobatics or other stunts were no longer a profitable show business. Curiously, this decline can be ascribed to scientific ballooning but mainly to the transformation of ballooning into an upper-class sport and pastime".

${ }^{27}$ G. Boffito, Il volo in Italia: storia documentata e aneddotica dell'aeronautica e dell'aviazione in Italia, Firenze, Barbera (1921), p. 216.

${ }^{28}$ Tissandier (1887). Op. cit., pp. 84; 79.

29 "The impatience of the public urged the flight" during Brioschi's flight in 1808. In: Boffito (1921). Op. cit., p. 264.

${ }^{30}$ Gyung Kim (2004). Op. cit., p. 153.

${ }^{31}$ For a history of popular science periodicals in the XIX century see: P. Govoni, Un pubblico per la Scienza. La divulgazione scientifica nell'Italia in formazione, Roma, Carocci (2002).

${ }^{32}$ E. Kirschner, Aerospace balloons, Aero Publishers (1985), pp. 13-14.

${ }^{33}$ Rolt (1966). Op. cit., p. 140.

${ }_{34}^{34}$ M. Lynn, Divining the enlightenment: public opinion and popular science in old regime France, ISIS 92 (2001) 34.

${ }^{35}$ James Glaisher in: Rolt (1966). Op. cit., p. 183.

${ }^{36}$ K. Turner, The Spectacle of Democracy in the Balloon Plays of the Revolutionary Period, Forum for Modern Language Studies 39 (2003) 241.

${ }^{37}$ Connaughton (1984). Op. cit., p. 71.

${ }^{38}$ Majrani (1999). Op. cit., p. 70.

${ }^{39}$ Glaisher (1869). Op. cit., p. 19

${ }^{40}$ Tucker (1996). Op. cit. , p. 147.

${ }^{41}$ Tucker (1996). Op. cit., p. 174.

${ }^{42}$ Rolt (1966). Op. cit., p. 192.

${ }^{43}$ Tucker (1996). Op. cit., p. 153.

${ }^{44}$ Tucker (1996). Op. cit., p. 144-5.

${ }^{45}$ Lynn (2001). Op. cit., pp. 36; 46.

\section{Author}

Cristina Olivotto took a degree in Physics in 2002 at the Università di Milano Bicocca. She has recently concluded her Ph.D. studies at the Università degli Studi di Milano; her topic of research concerns History of Physics and the final dissertation will concern the history of scientific ballooning, focused on the European cooperative flights undertook in the first Fifties of the XX century. E-mail: cristina.olivotto@unimi.it. 